\title{
CHEMICAL EDUCATION OUTSIDE A CLASSROOM - STEP BY
} STEP

\section{Iwona Maciejowska}

Department of Chemical Education, Faculty of Chemistry, Jagiellonian

University, Kraków, Poland

\begin{abstract}
Annotation
Typically, chemistry lessons unlike e.g. biology classes or environmental education are conducted solely within the four walls of the classroom or the chemistry lab. The outdoor activities are usually more difficult for a teacher to conduct compared to classes performed at school laboratory. Many difficulties can be avoid by detailed preparations. The step-by-step approach is presented. Limitations and profits of field trips are discussed also.
\end{abstract}

Key words: chemistry education, outdoor education, field trip.

\section{Introduction}

Taking young people away from their normal environment on what they perceive to be an expedition, even though it may be only a few kilometers down the road, has certain advantages over the use of most school grounds (Fieldwork Knowledge Library). Typically, chemistry lessons unlike e.g. biology classes or environmental education (Bogner, 1998; Lock \& Tilling, 2002; Stawiński, 2002) are conducted solely within the four walls of the classroom or the chemistry lab. In the past, industrial excursions, to show students "modern" technologies were quite popular in Eastern Europe (Downar, 1978; Burinskaia, 1989). Many teachers and researchers agree that it is worthwhile, to make use of all the possibilities provided by the environment outside the school (Lynch et al., 1999; Orlik, 2002; Rennie \&McClafferty, 1996; Stephenson \& Parvin, 2004; Kluza \& Maciejowska, 2007). The outdoor activities are usually more difficult for a teacher to conduct compared to classes performed at school laboratory. Many difficulties can be avoid by detailed preparations (Nowak, 2000).

\section{Various form of outdoor activities}

Outdoor activities may take various forms depending on the following factors:

1. If it is the number of participants, off-school activities may be offered:

- whole class

- one or a few 'scout' students. In this case, the participants should be made obliged to make a presentation/report during a regular class. The place of their visit may be e.g. parents` factory or grandparents' farm

2. If it is the time the students leave their school rooms:

- 1-2 quarter of time - Short visit to a place in the school e.g. going on a class outing to a school canteen (in order to learn basic food components), a surgery room (in order to learn bactericidal properties of $\mathrm{C}_{2} \mathrm{H}_{5} \mathrm{OH}$ or $\mathrm{H}_{2} \mathrm{O}_{2}$ )

- $0,5-1$ hour - Short visit to a place located closely to the school e.g. going to school garden or park surrounding the building (to make experiments concerning photosynthesis)

- A half-day or one day excursion e.g. to a museum of geology, to nearby cave (to learn about salts, crystals, limestone), to the lake (to observe eutrophication by fertiliser run off) 
- A week's residential course - the so-called green school or summer camp e.g. to country side (monitoring the state of the water in the area)

Short outdoor activities do not perturb the school work and do not bring organisational difficulties. Less experienced teacher should start with that kind of field classes. As children get older and teacher get more experienced the possibilities of getting away from the school grounds increase as a day trip or a residential course.

\section{Why? (the aim)}

It is worthwhile to leave the school walls to:

- $\quad$ provide relevant context for chemistry education

- raise the students' motivation through presenting chemistry as a subject which is directly connected with both real life and the natural environment around them

- raise the students' awareness of how advances in information technology and instrumentation are used in chemistry

- $\quad$ show the contributions of chemistry to society and the responsible use of scientific knowledge and evidence

- work up students' enthusiasm for activities that would ideally comprise all four spheres of the psyche: sensory and mental cognition, feelings and volition

- develop students' independence and self-reliance

- develop transferable skills such as: observation skills, data collection, data presentation, group work, time and work management.

Out-door activities bring everyday life closer to usually abstract school chemistry, show practical applications of theoretical knowledge, build up links with real world. Students will gain an understanding of how chemistry is used in many scientific pursuits. There is also a chance for students to take part in chemistry demonstrations, organized by colleges and universities, and to visit laboratories, thanks to which they can see and do interesting experiments which would be too difficult to perform in normal school conditions. In that way field lessons enlarge students motivation and effectiveness of teaching/learning process. Field trips give an unique opportunity to present interdisciplinary issues, safety regulation etc. Young people need to know that science is not a dry academic subject, that is real and exciting, and that it can be a fulfilling career (Harrison, 1998). Visit to local factory make students also aware of employers' requirements towards alumni. Lessons that take place outside of the traditional classroom setting have very good, direct effects on students and teachers as well. Thanks to them teachers can: actualise their chemical knowledge, broaden their knowledge (of for example new applying of chemistry), and refresh their enthusiasm for teaching that interesting subject.

\section{Where?}

Even in tiniest villages some places can be found which may come in handy for the teacher to cover the obligatory points included in the curriculum. Such places are for instance: a farmstead (covered topic: artificial fertilizers - salts), public institutions (e.g. police: topic detection of ethanol; health service: topics - analytical reactions; mass nutrition: topics properties of proteins and disaccharides), industrial plants (technological processes, polymers etc.), museums (e.g. university museums: topic - figures of distinguished chemists, history of chemistry), or fructose farm and orchard (salts, fertilizers, $\mathrm{Ca}(\mathrm{OH})_{2}$, photosynthesis, starch). Visiting chemical, construction, pharmaceutical etc. industry products fairs will help them in 
teaching lessons on the application of certain chemical substances. Showing students potential workplaces (quality tests laboratories, R\&D laboratories, production lines, sewage and water treatment plants, criminal laboratories) or places of study (laboratories and lecture halls at universities) will help to maintain students' interest in the subject. ${ }^{1}$

Fieldwork Knowledge Library developed and maintained by MST, IoE and British Ecological Society suggests for KS3: caves (solubility, acids, patterns of chemical reactions, factors affecting rates of reaction, reversible reactions, transition metal chemistry, equations), concrete (a mixture, sand, rods of iron, calcium, aluminium silicates) rubbish container (iron and steel, coated with zinc, corrosion, reactivity) metals (around the school and in the neighbourhood and even at the art galery, copper, tin, zinc, aluminium, lead), buildings materiales (granite, clay, mortar, sandstone) etc.

Yuri Orlik in his book Active methods of teaching and learning chemistry (Orlik, 2002) proposed for schools located outside large metropolis virtual trips by Internet e.g. to see Maria Curie Museum in Paris ${ }^{2}$. Many of the companies offer multimedia materials under the category of "virtual science trip". We can also have a look at some laboratories and production lines featured on the websites of big chemical, pharmaceutical or cosmetics companies and their associates. That could be the subject of a separate article on distance-learning. It is also worth mentioning that the Internet is often used as a platform for reporting on school trips that took place in reality. The entries found on students' blogs, for example, are a potential source of inspiration (as on possible destinations of science trips) as well as an effective means to learn about various perceptions of this form of education ${ }^{3}$

In the present part of this work, the focus is on several-hour trips (ca. 4 hours) that do not exceed the regular school timetable. The suggestions enumerated underneath apply to the city of Krakow. Krakow is the capital of the Malopolska region situated on the Vistula with the population of 800,000 .

\begin{tabular}{|l|l|}
\hline \multicolumn{1}{|c|}{ Syllabus-based topic } & \multicolumn{1}{c|}{ Place of actualisation } \\
\hline crystals, crystallization, ionic bond & Salt Mine, $\left(\right.$ Wieliczka $^{4}$, Bochnia $^{5}$ ) \\
\hline natural resources & $\begin{array}{l}\text { the Museum of Geology } \\
\text { (University of Minning and Metallurgy) }\end{array}$ \\
\hline $\mathrm{CaCO}_{3}$ and its reaction & Jurassic Region Kraków - Częstochowa \\
\hline
\end{tabular}

\footnotetext{
${ }^{1}$ Malone College, Instrumental chemistry field trip http://www.malone.edu/2110, $(2007.11 .08)$

${ }^{2}$ The Curie Museum http://www.curie.fr/fondation/musee/musee.cfm/lang/ gb.htm, (2007.11.08)

${ }^{3}$ Blog Baroque http://juxtaposethebaroque.blogspot.com/2007/08/field-trip.html, The Saloon discussion list http://aoe3.heavengames.com/cgibin/forums/display.cgi?action $=\mathrm{ct} \& \mathrm{f}=2,34198,0,10$, Environmental Chemistry Field Trip http://www.bigroom.org/wordpress/?p=71, (2007.11.08)

${ }^{4}$ Wieliczka Salt Mine http://www.kopalnia.pl/home.php?action=\&id language=2\&, (2007.11.08)

${ }^{5}$ Salt Mine in Bochnia http://www.silentwall.com/BochniaI.html, (2007.11.08)
} 


\begin{tabular}{|l|l|}
\hline $\begin{array}{l}\text { dissolution, precipitation reactions, } \\
\text { properties of } \mathrm{Cl}_{2} \text { and phenols }\end{array}$ & Water Treatment Plant Kraków - 'Kujawy' ${ }^{6}$ \\
\hline $\begin{array}{l}\text { combustion processes, } \\
\text { gas and dust air pollution }\end{array}$ & $\begin{array}{l}\text { power stations Krakow -'Lęg'7 } \\
\text { Environmental Inspectorate (WIOŚ) }\end{array}$ \\
\hline Catalysis & road police patrol (car catalysts) \\
\hline $\begin{array}{l}\text { redox reactions } \\
\text { air, the properties of its constituents, } \\
\text { oxygen liquefaction } \\
\text { Wróblewski) }\end{array}$ & Metallurgical Factory Mittal Steel Poland ${ }^{8}$, \\
\hline $\begin{array}{l}\text { silica, glass, crystalline and amorphous } \\
\text { substances }\end{array}$ & the Institute of Glass and Ceramics \\
\hline $\begin{array}{l}\text { the properties of hydrocarbons, } \\
\text { petroleum }\end{array}$ & the National Fire Brigade \\
\hline $\begin{array}{l}\text { detergents, soaps, esters } \\
\text { vitamin C }\end{array}$ & the Cosmetics Factories Krakow - 'Miraculum' \\
\hline
\end{tabular}

The places to visit and the way in which these classes are taught obviously depend on the age of the students: it can encompass anything from a visit to a supermarket and reading through foodstuff ingredients, through ph tests on spring water, a visit to a mine or metal smelting works (including a consideration of chemistry of the processes carried out, disposal of spoil and dealing with associated atmospheric pollution), to work in a professional laboratory.

\section{How to organize such classes?}

The organization of such outing comprises a few phases, but the step-by-step approach guarantees an educational success.

1. PREPARE A LIST OF PLACES that might be of interest for topics in the compulsory syllabus.

2. CHECK how many of them are available to the class (list verification) - some of them, e.g. Water Treatment Plant or numerous museums have prepared special activities for children and youth/young people (arrange for and collect the offers); at some other places it is possible to obtain a permission to visit with the guidance of an employee whom you know well. It is vital to establish regular co-operation with the appropriate institution, which is sometimes possible with the assistance of the students' parents.

\footnotetext{
${ }^{6} \mathrm{MPWiK}$ http://www.mpwik.krakow.pl/o nas/galeria/oczyszczalnia kujawy/, (2007.11.08)

${ }^{7}$ EC Krakow http://www.eckrakow.pl/index.html, (2007.11.08)

${ }^{8}$ Arcelor Mitkal Poland S.A. http://www.mittal-steel.pl/default.aspx?docId=1550\&mId1=682, (2007.11.08)

${ }^{9}$ Jagiellonian University Museum, http://www3.uj.edu.pl/Muzeum/pic1/20.html, http://www3.uj.edu.pl/Muzeum/pic1/17.html (2007.11.08)
} 
3. CHOOSE a suitable place. Make a preliminary site visit. You should decide if the place is suitable (e.g. not too childish, enough scientific) and safe. Check the transportation details and how much it takes to get to the place (e.g. by public transport). Ensure the pedagogical care during the trip (e.g. adult volunteers and parents - if allowed, a group of 10-12 pupils to one adult). The teacher in charge needs to make sure the volunteers know what is expected of them. Fulfill obligatory formal requirements e.g. signed permission forms, list of students.

4. AGREE on the time of outing with the parents, other teachers, school headmaster and the obviously a host.

5. PREPARE CHILDREN for the trip:

$\square$ Organizational issues - give information as to: where, when, for how long, what to take, what to wear, divide students into group, nominate group leaders

$\square$ Content-related matters - There are two quite different approaches to introducing a field course: culture shock (it is not recommended by author) or prepared for what to expect. In the case of that second method, organizing introductory classes and distributing the tasks to be carried out during the trip: individual or group based, e.g. 'observe...' 'find out...', 'take notes of...', 'conduct a interview', 'take a water sample', 'make a photo...'etc. in the form of work sheet to focus attention. This can be done by presenting them with a list of questions, which they are supposed to answer during the outdoor classes. Clear instructions help students to learn.

\section{FIRE student's IMAGINATION.}

7. ANTICIPATE everything (including 'the unpredictable': steps taken in case of anything that may happen e.g. road accident, bad weather, possible refreshments, tickets, toilets, etc.), BE AWARE of safety issues, have a plan for emergencies!

\section{GO, DO WORK AND COME BACK.}

9. SUM UP (collect and discuss reports, results of measurements, observations; prepare photos or posters exhibition, write papers to school journal etc.), integrate in the students' system of knowledge AND EVALUATE.

The safety of the participants of a science trip is absolutely essential and any contentrelated benefits would not justify any negligence in this area. On one of the Internet forums you can find an adequate description ${ }^{10}$ :

'Many moons ago, I took a group to a glass recycling facility (really cool) but I didn't visit first and didn't consider that the ground may be covered with glass (duh?) so I had to exclude some students from entering because they did not have proper foot attire'.

The younger the students, the more time is necessary for meritorious preparation. It applies both to the students - to make them understand what they are going to watch or to take part in and to the guidance persons - to make them adjust and fine-tune their comments to the level of knowledge and perception capabilities of the students. The older the students the less effort is necessary for the organization of activities (the students should take over the initiative, as well as should assist in organizational issues, while the number of people looking after the

\footnotetext{
${ }^{10}$ Chemistry Education Discussion List http://mailer.uwf.edu/listserv/wa.exe?A2=ind0702\&L=chemed-1\&P=48584, (2007.11.08)
} 
students as per the school regulations reduces). The participation of students in organizational outing guarantees the development of their transferable skills

It is also reasonably to invite specialists to chemistry classes as an alternative to the above-mentioned activities (Harrison, 1998; Holbrook \& Rannikmae, 2001). Certainly, such meetings also need special preparation in order to provide the children or youth with the scientifically sufficient explanation in an understandable way, or will e.g. a process of production.

In the second part of this work, the focus is on one week scientific trip- residential course

Organising shorter or longer scientific trips for young people interested in a particular subject is by no means a new idea.This form of education is used to great effect by Petnica Science Center ${ }^{11}$ for example. In Poland, so called 'green schools' - a weekly out-of-town stay of a class with chosen teachers (1-3) - are quite popular. The Salter's Institute provides chemistry camps which offer enriched out of classroom activity ${ }^{12}$

Advantages of residential courses incudes: focus on a single area of knowledge for several days away from the distractions of home and a school day, flexibility of teaching and learning styles - lectures, tutorial, training in the use of equipment, group work, discussion etc, motivation, efficient use of time. Social interaction through learning is developed: on a field course students often start to appreciate that the staff are mentors rather than teachers and they also learn from working with each other in an unfamiliar situation ((Fieldwork Knowledge Library).

There are two ways of organising a residential field course.

- Use a course provided by a professional centre

- $\quad$ Organise own field trip.

The program guidelines (aims) for the field course usually include delivery of educational content contained in the syllabus for Chemistry, Biology as well as an interdisciplinary Ecology course (so called in Poland 'environmental pathway'). A location for the field trip should be selected which would be relevant to the subject of the lessons and the trip's aims. In the given example ecology and environmental protection was a theme of field trip to Zakopane, south part of Poland, Tatra Mountains (Maciejowska, 2007). The teaching program was structured in such a way as to prepare the students to take part in an educational game (role play game) held on the last day of the trip entitled: "A Sitting of the Commune Council of Zakopane".

Necessary information was collected during field trip activities, which included:

○ a walk to the valley to survey the planned location for the project (investment),

- a visit to a biological sewage treatment plant (run by the SEWiK water and sewage company) to find out about sewage treatment methods and the potential (limitations) of the sewage treatment plant,

- a meeting with the Vice-mayor of Zakopane who is responsible for municipal utilities and the Head of the Department of Environmental Protection of the Municipal Council,

\footnotetext{
${ }^{11}$ Petnica Science Center WWW.psc.ac.yu, (2007.11.08)

${ }^{12}$ Salter's Institute http://www.salters.co.uk/camps/index.htm , (2007.11.08)
} 
- a visit to the Tatra National Park Museum (to find out about the history of conservation in the Tatra Mountains and the surrounding area) and the Tatra Museum (to find out about the natural features of the land and the life and work of the local inhabitants),

- presentation of an alternative source of heating energy based on the example of Geotermia Podhalańska (an geothermal energy company).

The final stage of the game involved creating an imaginary commune council and asking it to consider an application for building permission and establish building criteria for a new hotel, restaurant and sports complex. in the periphery of Tatra National Park. The debate ended with a verdict expressed by the decision-makers.

It is valuable to show that not only can applied chemistry (chemical and related industry) be responsible for environmental degradation but a knowledge of modern chemistry offers the ways to overcome these problems. Another important element of long term field trips is usually research work. Amateur environmental analysis has been growing in popularity in Poland since the 1990s and is already supported by a considerable body of reference material (Hafnem, 1993; Łopata, 1994; Łopata \& Maciejowska, 1994). Also non-governmental organisations organise or have organised activities of this kind. For example, for many years the Polish Scouting and Guiding Association has organised science field trips (lasting 3 weeks) some of them Chemistry-related (Górka \& Kowalski, 1987; Maciejowska, 1993; Maciejowska, 2001)

\section{What are the limitations of the outdoor activities?}

This form of the implementation of especially environmental topics is quite popular with many teachers in Poland (Buchcic, 2000) and other countries ${ }^{13}$. The percentage of such activities gradually diminishes with higher levels of education due to a large amount of obligatory content.

Undoubtedly the fact that outdoor school activities are so time-consuming is their weak disadvantage. They require scrupulous preparation and a summing up stage and very often the involvement of the adult volunteers. Security requirements, which are sometimes difficult to meet, are another issue. Similar opinions can be found on educational Internet forums ${ }^{14}$ :

'It is obviously logistically difficult for many classes to go on field trips and plants generally don't like big groups. Additionally there may be liability issues(if that isn't enough)!!'

and 'Our procedure for field trips has changed drastically over the years. We now have to have the school board's permission to go and must write a suitable letter outlining the educational and economic benefis of the trip and why it is worth taking the kids out of school for a day. We must also be quite humble and kow-tow appropriately. All our chaperones must be fingerprinted and approved by the county (perhaps even the folks at the field trip, but I've never asked for clarification), permission slips and medical releases, school and on-site dresscodes.'

\footnotetext{
${ }^{13}$ Environmental chemistry field trip http://www.bigroom.org/wordpress/?p=71, Montgomery Blair High School's Online Students Newspaper http://silverchips.mbhs.edu/inside.php?sid=4266, Onekama Consolidated Schools http://www.onekama.k12.mi.us/e2002/g5/tree/soil.chem.htm, Teacher Web http://teacherweb.com/WA/RiversEdgeHighSchool/AnnAutrey/h0.stm, (2007.11.08)

${ }^{14}$ Chemistry Education Discussion List http://mailer.uwf.edu/listserv/wa.exe?A2 $=$ ind0504\&L $=$ chemed-1\&P=26298, http://mailer.uwf.edu/listserv/wa.exe?A2 $=$ ind0702\&L $=$ chemed-1\&P=48584,,$(2007.11 .08)$
} 
It seems, however, that the advantages of the method described outweigh its disadvantages.

\section{References}

Bogner, F.X. (1998). The Influence of Short-term Outdoor Ecology Education on Long-Term Variables of Environmental Perspective, Journal of Environmental Education, 29, 4, 17-29.

Buchcic, E. (2000). Environmental Education on the So-called „Green Schools”, In R. Sulcova

(ed.) Science and Technology Education in New Millenium, PERES Publishers, Prague, 175-178.

Burinskaia, N. (1989) Didactical excursion in chemistry. Moscow, (in Russian).

Dovnar, I. (1978) .Excursion in Chemistry. Minsk, (in Russian).

Fieldwork Knowledge Library http://www.fieldworklib.org/default.asp (2007.11.08)

Górka, P. \& Kowalski, S. (1987) Zbiórka harcerska z ... chemią, HOW, Kraków.

Hafner, M. (1993). Ochrona Środowiska. Księga eko-testów do pracy w szkole i w domu, Polski Klub Ekologiczny, Kraków.

Harrison, B. (1998) Industrial Links - Purposes and Practice in: ASE Guide to Secondary

Education, Mary Ratcliffe (ed.), ASE, Hatfield, 241-247.

Holbrook, J. \& Rannikmae, M. (2001) Evaluating Best Practice in Education-Industry

Partnerships, 6th ECRICE and 2nd ECCE Proceedings, Aveiro S32.

Kluza, M. \& Maciejowska, I. (2007) Not only in Schools - Informal Science Education, 50th

Annual Meeting of Polish Chemical Society \& 11th ICCE-DCE, Torun.

Lock, R. \& Tilling, S. (2002). Ecology fieldwork in 16 to 19 biology, School Science Review, 84 (307), 79-87.

Łopata, K. \& Maciejowska, I. (1995). Chemiczne i biologiczne wskaźniki czystości wód naturalnych. Chemia w szkole, 1, $32-36$.

Łopata, K. (1994) Chemia a środowisko. Zbiór ciekawych doświadczeń, WSiP, Warszawa.

Lynch, I., Geary, N., Hagaman, K., Munson, A. \& Sabo, M. (1999) Building the Interest of High

School Students for Science - a PACT Ambassador program to Investigate Soap Manufacturing and Industrial Chemistry, Journal of Chemical Education, 76, 2, 191-192.

Maciejowska, I. (1993). Elementy chemii środowiska realizowane na zajęciach pozalekcyjnych i pozaszkolnych, Zjazd PTChem i SITPChem, Toruń, S10 -P8

Maciejowska, I. (2001). Nietoperz, Poradnik metodyczny dla nauczycieli i instruktorów, Kraków.

Maciejowska, I. (2007), Field Trips as a Way of Working with a Class with an Extended

Chemistry and Biology Syllabus, Roczniki Polskiego Towarzystwa Chemicznego, http://www.pg.gda.pl/chem/InneJednostki/PTChem/Roczniki 2007/all annals.pdf, (2007.11.08)

Nowak, A. (2000) Preparation and Conduction of Field Classes, in R. Sulcova (ed.) Science and Technology Education in New Millenium, PERES Publishers, Prague, 262-266.

Orlik, Y. (2002).QUíMICA. Métodos activos de enseñanza y aprendizaje, Mexico, 321-326.

Rennie, L.J. \& McClafferty, T.P. (1996) Science centres and science learning, Studies in Science Education, 27, 53-98.

Stawiński,W. (ed.) Dydaktyka biologii i ochrony środowiska (2000). Warszawa.

Stephenson, M. \& Parvin J., (2004), Learning science at industrial sites, in M.Braund \& M. Reiss, Learning Science Outsider the Classromm, London, RoutledgeFalmer.

Received 24 September 2007; accepted 30 October 2007

\section{Dr. Iwona Maciejowska}

Faculty of Chemistry, Jagiellonian University

30-525 Ingardena 3, Cracow, Poland

E-mail: maciejow@chemia.uj.edu.pl 